\title{
Caminhando por sítios de memória da ditadura argentina: o ex Casino de Oficiales e o Ex Club Atlético.
}

\author{
Walking through places of memory of the Argentine \\ dictatorship: The Casino de Oficiales and the Club \\ Atlético.
}

\section{RESUMO}

O presente texto apresenta a pesquisa de campo realizada em Buenos Aires em novembro de 2017, como parte da investigação de mestrado "Memórias de dor em Buenos Aires ex Centros Clandestino de Detención, Tortura y Extermínio (ex CCDTyE) a lugares de memória e consciência", desenvolvida na Faculdade de Arquitetura e Urbanismo da Universidade de São Paulo (FAU-USP). Exponho aqui a análise realizada a partir do trabalho em campo de dois dos cinco ex Centros Centros Cladestinos de Detención Tortura y Exterminio, hoje sítios de memória da última ditadura argentina (1976-1983), localizados em Buenos Aires: o ex Casino de Oficiales, atual Museu de Sítio ESMA e o Ex Club Atlético, hoje um sítio arqueológico. A partir dos dois lugares busco tanto expor possibilidades de análise espaciais de locais que foram palco de violências no passado; quanto iluminar dois caminhos distintos de trabalho com a memória da violência a partir e através da cidade.

Palavras-chave: Cidade - Ditadura - Argentina - Sítio de Memória Topografia

\begin{abstract}
This text aims to present the fieldwork developed in Buenos Aires in November of 2017, as part of the master's investigation "Hurtful memories in Buenos Aires: from Clandestine Torture, Detention and Extermination Centers (ex CCDTyE) to places of memory and consciousness", developed at Faculdade de Arquitetura e Urbanismo da Universidade de São Paulo (FAU-USP). I expose an analysis constructed from the fieldwork about two CCDTyE, today places of memory of the last Argentine dictatorship (19761983) located in Buenos Aires: the former Casino de Oficiales, current Museo de Sitio ESMA; and the ex-Club Atlético, today an archaeological site. From these two places, I intend to illuminate two distinct ways of working with the memory of the military dictatorship with the broader objective of illuminating critical possibilities of representing the memories of violence today, from and through the city.
\end{abstract}

Keywords: City - Military Dictatorship - Argentine - Memory site Topography

* Mestranda do curso de Pós-Graduação em Arquitetura e Urbanismo pela Universidade de São Paulo (FAU-USP), Brasil. CV: http://lattes.cnpq.br/1370443231854326 


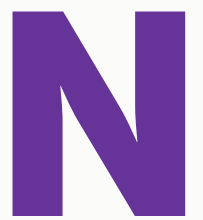

osso dia a dia é bombardeado por imagens, notícias de violências e mortes as mais atrozes. Volta e meia nos deparamos com algum episódio de violência na cidade e sistematicamente os acompanhamos pela TV, revistas ou jornais. As mortes causadas por violências policiais, as guerras e conflitos os mais diversos nos dão a sensação de que o mundo está se enchendo de ausências, que se estendem por todo o território urbano, social e político e formam um cenário devastador (Diéguez, 2013). Compartilhando as inquietações de lleana Diéguez (2013) venho me perguntando: como é possível conviver com isso? Se é necessário habitar para sobreviver, não temos escolha, a não ser buscar maneiras de lidar e transformar esse cotidiano.

Na Argentina, a luta pública contra o terrorismo de Estado por parte de familiares de desaparecidos, associado a um conjunto de medidas governamentais inéditas - como o Juício a las Juntas - construíram uma memória comum sobre a última ditadura militar (1976-1983) (Silvestri, 2000). Como parte desse movimento, grupos da sociedade civil vêm reivindicando locais de tortura, memoriais e praças públicas como provas jurídicas, espaços de significados políticos, simbólicos e didáticos dos 30.000 desaparecidos. Hoje, andando pelas ruas de Buenos Aires, é difícil não se deparar com algum desses lugares, que já são mais de 250 na cidade (Memoria Abierta, 2010). Esses elementos transformam a paisagem da capital federal e conformam uma topografia ${ }^{1}$ difícil e, para muitos, extremamente dolorosa.

O presente relato expõe um exercício de aproximação com essa topografia - que não é só espacial, mas política e social - por meio da pesquisa em campo realizada em Buenos Aires em novembro de 2017. A viagem inseriu-se na pesquisa de mestrado "Memórias de dor em Buenos Aires: de ex Centros Clandestinos de Detención, Tortura y Extermínio (CCDTyE) a lugares de memória e consciência", desenvolvido na FAU-USP sob orientação do Prof. Dr. Renato Cymbalista e apoio da Fundação de Amparo à pesquisa do Estado de São Paulo (FAPESP). $\mathrm{Na}$ investigação tomo como recorte a Dirección Nacional de Sítios de Memoria (antes Red Federal de Sítios de Memória) na Argentina, com o foco em cinco dos ex Centros Clandestinos de Detención Tortura y Exterminio (Ex-CCDTyE) de Buenos Aires que a compõem e hoje são lugares de memória: a Ex-Esma, o Ex-Olimpo, o Ex-Virrey Cevallos, o Ex-Club Atlético e o Ex-Centro de Automotores Orletti. A partir do objeto de pesquisa analiso como cada um destes sítios de memória, cenários da barbárie no passado trabalha suas especificidades e se completam (ou não) com os demais, configurando uma narrativa complexa e não redundante na cidade. Para tanto, compreendo-os por meio das relações de tensões que os construíram: entre as relações dinâmicas dos grupos envolvidos nos trabalhos de memória; e os signos (como aquilo que comunica), ferramentas e técnicas (arquitetônicas, arqueológicas, gráficas, propagandísticas, entre outras) escolhidos para representar espacialmente a memória da ditadura. Em última instância trata-se de pensar possibilidades políticas, estéticas e éticas de representar as memórias de violência na cidade contemporânea e, ainda, desde o campo da arquitetura e do urbanismo, com o objetivo mais amplo iluminar possibilidades críticas,

1 A noção de uma topografia de dor, de Gabi Dolff-Bonekämper (2002), refere-se à ramificação de percursos, lugares e espacialidades que as memórias relativas à traumas conformam nos espaços urbanos devido à sua intima ligação topográfica. 
analíticas ou práticas, para pensar a mesma questão no Brasil².

A última ditadura argentina, cujas memórias encarnadas no espaço são tema da dissertação, aconteceu em 1976, com o golpe militar que derrubou a presidente Maria Estela Martínez, com a justificativa de conter o mau governo, o crescimento da inflação e as ações guerrilheiras de esquerda. Chamando a ação de "reorganização nacional", os militares iniciaram assim a época mais violenta da história do país e uma das mais sanguinárias da América Latina, o que representou tanto o extermínio de milhares de pessoas, quanto a modificação de "[...] laços e relações sociais, convenções sociais, aspectos da vida cotidiana e formas de mediação política3" (Fereinstein, 2014, p. 49, tradução da autora).

Nesse processo, os centros clandestinos foram concebidos como uma tecnologia central. Seja para eliminar qualquer forma de resistência - especialmente membros das guerrilhas de esquerda; seja para disciplinar e assombrar a sociedade - pois encontravam-se extremamente emaranhados na trama urbana e, embora clandestinos, se deixava escapar deles ruídos e gritos provenientes das torturas, que tratavam de aterrorizar a população. Calcula-se mais de 700 lugares do tipo em todo país, criados para abrigar as torturas, interrogatórios e manter os presos políticos encarcerados na ditadura militar. Mas hoje, aqueles recuperados e/ou sinalizados pelo Estado, vêm se mostrando poderosas ferramentas de luta política, de transmissão de conhecimentos e de afirmação de uma história de graves violações aos direitos humanos.

Até o momento a investigação esteve dividida em dois momentos centrais: um primeiro desenvolvido no Brasil, voltado principalmente à análise teórica das referências bibliográficas; e o segundo realizado na Argentina, por meio da pesquisa em campo. No Brasil me aproximei principalmente de autores que abordam o tema da memória social e tratam das relações entre memória cultural ${ }^{4}$ e direitos humanos - como Elizabeth Jelin (2002; 2017), Ana Guglielmucci (2011), Hugo Vezzetti (2001; 2009), Andreas Huyssen (1991; 2000; 2003; 2014) e Aleida Assman (2011), para citar alguns. E a viagem tratou-se, mais que nada, do contato com os objetos de estudo da pesquisa, por meio de sistemáticas visitas e registros dos mesmos, de entrevistas com os atores sociais que os constroem em seu dia a dia, e da coleta de documentos referentes aos sítios.

Neste relato exponho as análises espaciais de dois sítios, dos cinco estudados, realizadas a partir do trabalho de campo: a Ex Escuela Mecánica de la Armada, na qual o foco centra-se no Museu de Sítio Esma, ex Casino de Oficiales, cérebro das práticas repressivas na Argentina; e o ex Club Atlético, no qual há um sítio arqueológico, localizado também onde estava o centro clandestino. Ambos partem de uma história comum, mas iluminam dois caminhos distintos

2 Afinal, embora ações legais, simbólicas e analíticas que lá já foram possíveis, aqui todavia não tenham sido, notese que, com relação aos lugares de memória, as iniciativas no Brasil vêm sendo gradualmente ampliadas. Em São Paulo, por exemplo, embora só haja um memorial como os ex-CCDTyEs, o Memorial da Resistência, existem outros dois planejados: o da Auditoria Militar e nas dependências do DOI-CODI. Pensar os ex CCDTyE sob a perspectiva de rede, ideia da dissertação, aponta então possibilidades para lidar com o conjunto de lugares que vêm se formando, em que os distintos projetos se complementem e não sejam redundantes.

3 "bonds and relationships, social conventions, aspects of daily life, forms of political mediation -in short, to transform the concrete and abstract operations of power within a given society"

4 A noção de Memória Cultural, cunhada por Aleida Assman (2011), diz respeito às memórias encarnadas em filmes, fotografias, monumentos e também na arquitetura. 
de agenciamento dessa memória, pois também mobilizam histórias e foram construídos por disputas específicas, que só podem ser contadas a partir deles. Pensando-os em relação, busco identificar suas formas específicas de diálogo com o público, suas conexões e particularidades, que cooperando para a construção de uma narrativa complexa e não redundante da memória da ditadura na cidade.

\section{Percursos}

O primeiro percurso ocorreu na Ex Escuela Mecánica de la Armada, especificamente em um dos dezessete edifícios que compõem o conjunto: o ex Casino de Oficiales, atual Museo de Sítio Esma, inaugurado em 2015 e dirigido pela museóloga Alejandra Naftal ela própria ex-detenta desaparecida. Trata-se de um museu cuja plataforma central não é seu acervo, mas o edifício, que é muito particular: entre 1976-84 passaram por lá cerca de 5.000 detidos desaparecidos, que sofreram graves crimes de lesa humanidade; desde lá foram elaboradas outras práticas repressivas, como os Vuelos de la Muerte ${ }^{5}$; e ele compõe um monumental complexo de 29 edifícios, ocupados na época pelas Forças Armadas, em 17 hectares do bairro de Nuñez, na larga e agitada Av. del Libertador. O conjunto, considerado o cérebro das práticas repressivas, abriga hoje quatorze organizações de direitos humanos e seu museu, que já recebeu mais de 240.000 visitantes, foi lançado como candidato a patrimônio cultural da humanidade pela UNESCO em 2017. Assim, seja por sua complexidade enquanto tecnologia repressora; seja por seu uso hoje, pode ser considerado o centro clandestino de maior importância simbólica do país (Guglielmucci, 2011). Além disso, como desenvolveremos nas próximas páginas, podemos afirmar que dentre os ex-CCDTyEs o ex Casino de Oficiales é o mais inserido no circuito turístico da cidade, em grande medida por seu caráter de museu.

Imagens 1 e 2 - Edifícios da Ex Escuela Mecánica de la Armada

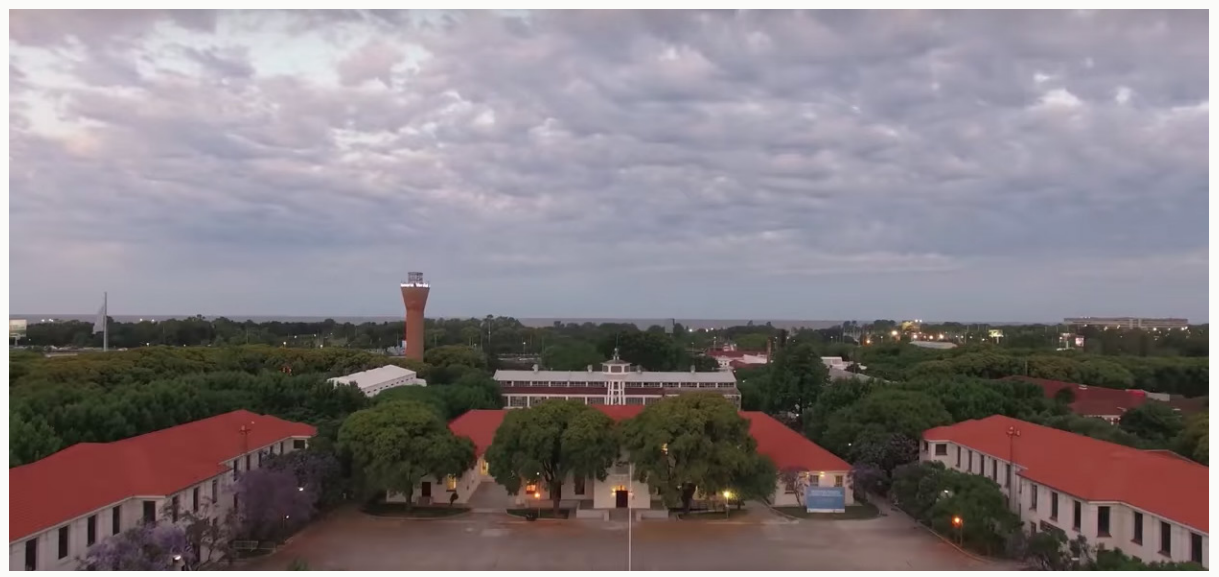

5 Os chamados Vuelos de la Muerte foram uma prática de extermínio desenvolvida pelos militares, que consistia em transitar com os detidos dos ex-centros clandestinos e atirá-los vivos no Mar del Plata. 


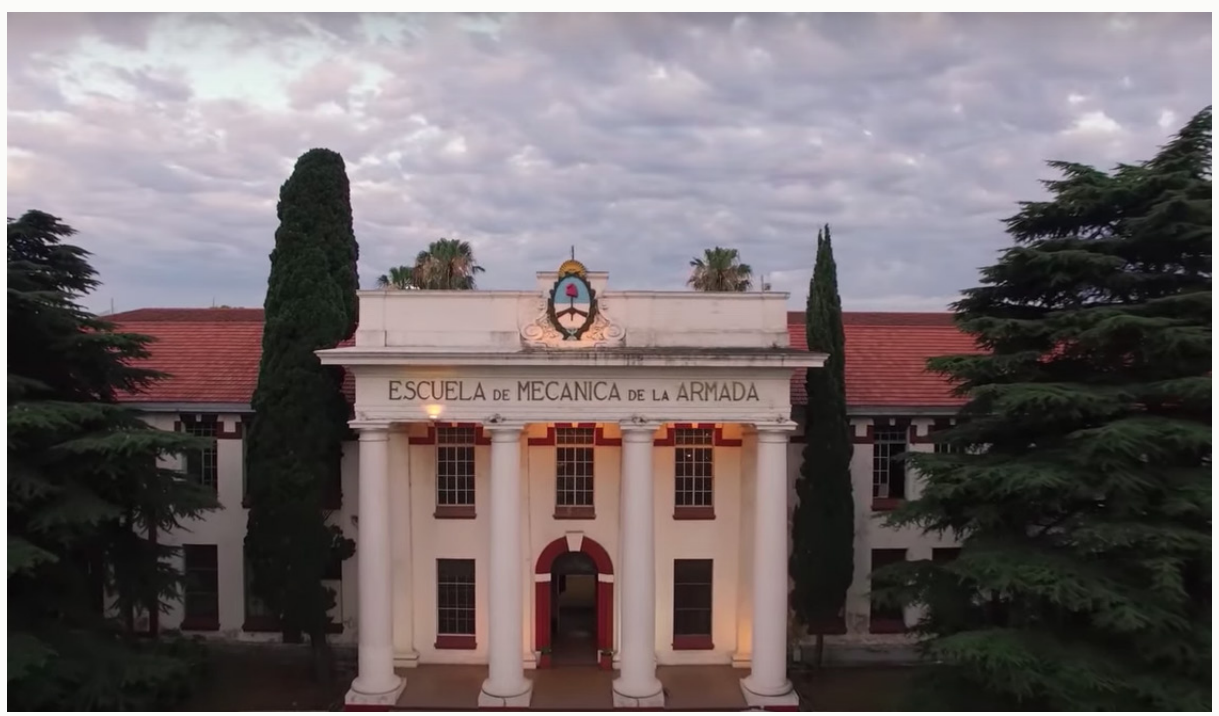

Fonte: Imagem retiradas do vídeo "Ex Esma - Candidata Patrimonio de la Humanidad por el Nunca Más". Disponível em: https://www.youtube.com/watch?v=3AKeerlUFI4\&t=54s > Acessado em 05 de maio de 2018.

Adentrando o ex-Casino de Oficiales, atual Museo de Sítio Esma, por uma porta de vidro, repleta de fotos $3 \times 4$ ampliadas dos desaparecidos, ingressa-se no hall. Lá, a guia fornece as instruções iniciais para o visitante que vai fazer o percurso proposto pela instituição: não se pode comer ou beber, nem encostar nas paredes, "Por motivo de segurança. O espaço inteiro é prova jurídica dos julgamentos ainda em curso". Trata-se da Megacausa ESMA, um conjunto de processos judiciais inter-relacionados que envolve a maior quantidade de pessoas, dentre os processos por crimes lesa-humanidade da ditadura. Segundo Alejandra Naftal ${ }^{6}$, justamente por esta razão, o projeto expográfico partiu da ideia de manter o edifício tal qual foi entregue às organizações de direitos humanos em 2004. Cada detalhe do edifício importa, pois os sobreviventes, por estarem vendados quando presos, lembram apenas de um ou outro detalhe que puderam observar pelo vão dos capuzes.

O museu encontra-se organizado em estações temáticas, de acordo com as funções dos ambientes de quando era centro clandestino: Hall, Contexto Histórico, De Escuela a Centro clandestino, Capucha, Capuchita, Pañol, Pecera, La Casa del Almirante, Los Jorges, Sótano, Traslados, Salón Dorado. Contudo, apesar da ideia guia do projeto ter sido a manutenção do edifício tal qual encontrado, já na primeira estação percebe-se que o espaço foi, de alguma forma, modificado. Em Contexto histórico um vídeo projetado em uma ampla parede, com ilustrações, fotos e imagens de arquivos, oferece um panorama da luta política maior que originou aquele lugar, introduzindo as questões a serem desenvolvidas ao longo do percurso. Configura-se, assim, como o primeiro ponto alto da narrativa?.

6 Depoimento disponível em https://www.youtube.com/watch? $v=F l a p t b 9 J E e 8 \& t=113 \mathrm{~s}>$ acessado em 16/09/2017.

7 Entrevista concedida por Alejandra Naftal à autora, em Buenos Aires, no dia 15/05/2018. 
Imagem 3 - Sala Contexto Histórico

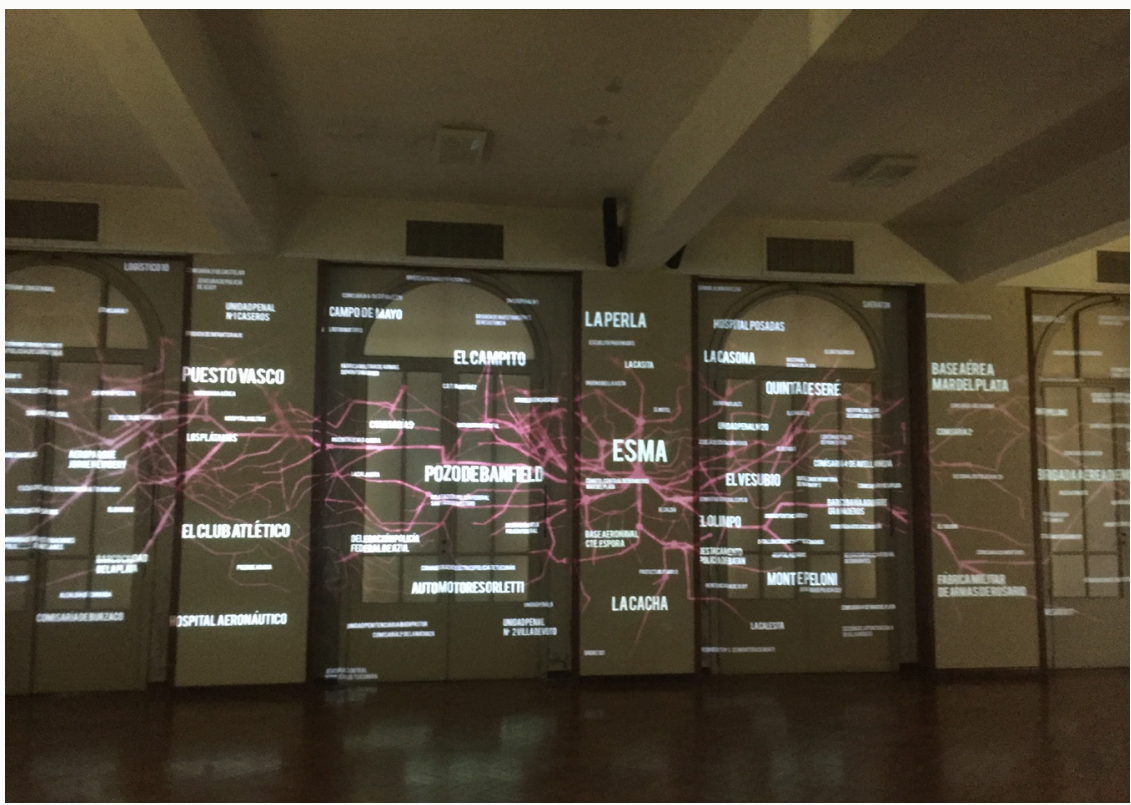

Fonte: Registro da autora, Buenos Aires, 2017.

Percorrendo sala a sala nota-se, em todos os ambientes, painéis de vidro fumê com base de concreto, que funcionam como plataforma para reproduções de documentos, fotos, cartas e depoimentos. Reproduções, pois os objetos originais se encontram na Justiça, e todos os documentos e informações mobilizadas no museu foram apresentados, investigados e autenticados legalmente - seja pela Comisión Nacional sobre la Desaparición de Personas (CONADEP), pelo Juício a las Juntas Militares ou por meio da Megacausa ESMA. Desse modo, embora outras fontes - como artigos acadêmicos, depoimentos, filmes e reportagens tenham sido utilizados no projeto expográfico ${ }^{8}$, optou-se por apresentar ao público apenas as fontes homologadas pela Justiça. Segundo os documentos administrativos recolhidos em campo, onde expunha-se um primeiro projeto e suas diretrizes em 2013, a instituição, sendo pública, buscou assim apresentar-se como uma voz estatal.

Nesse mesmo sentido, as intervenções museológicas são descoladas, contrastam e distinguem-se das paredes descascadas, riscadas e repintadas do espaço original. Assim estão implantados não apenas os painéis, mas uma estrutura de madeira sobreposta ao piso original e as placas de acrílico que, apoiadas em vigas e paredes, remetem-se aos depoimentos que mencionaram esses elementos. Segundo a guia que acompanhou a visita, o descolamento dos objetos foi uma medida para evitar a modificação do espaço e facilitar os trabalhos de conservação. Os painéis, a plataforma de madeira e as projeções podem ser facilmente removidos, caso seja necessário intervir ou caso apareça um novo depoimento, que necessite mobilizar o edifício como prova material. Mas também trata-se de uma posição ética e estética. As intervenções deixam clara a história da qual fazem parte e, como no caso dos painéis e projeções, permitem ver através.

8 Entrevista concedida por Alejandra Naftal à autora, em Buenos Aires, no dia 15/05/2018. 
Ademais também cooperam para que o sítio seja entendido como museu. Afinal, sabe-se que painéis e placas, fazem parte de um vocabulário comum aos museus de arte contemporânea (por exemplo), sendo sistematicamente utilizados em exposições para transmitir conhecimentos mais amplos sobre uma obra. Entretanto, no caso de um Museo de Sítio há um paradoxo bastante complexo nesse processo de musealização: como afirma Aleida Assman (2011) a remodelação em memoriais e museus a favor da autenticidade significa, inevitavelmente, a perda de sua autenticidade. No caso específico, as intervenções - sejam projeções, painéis ou pisos - não apenas o alteram, como parecem competir entre si e encobrir a maior parte do espaço original. Mas, por outro lado, cumprem uma função fundamental: torná-lo esteticamente agradável (por mais contraditório que isso possa parecer), confortável e inteligivel para atrair e ser compreendido por um grande público.

Imagem 4 - Painéis no Museo de Sítio Esma

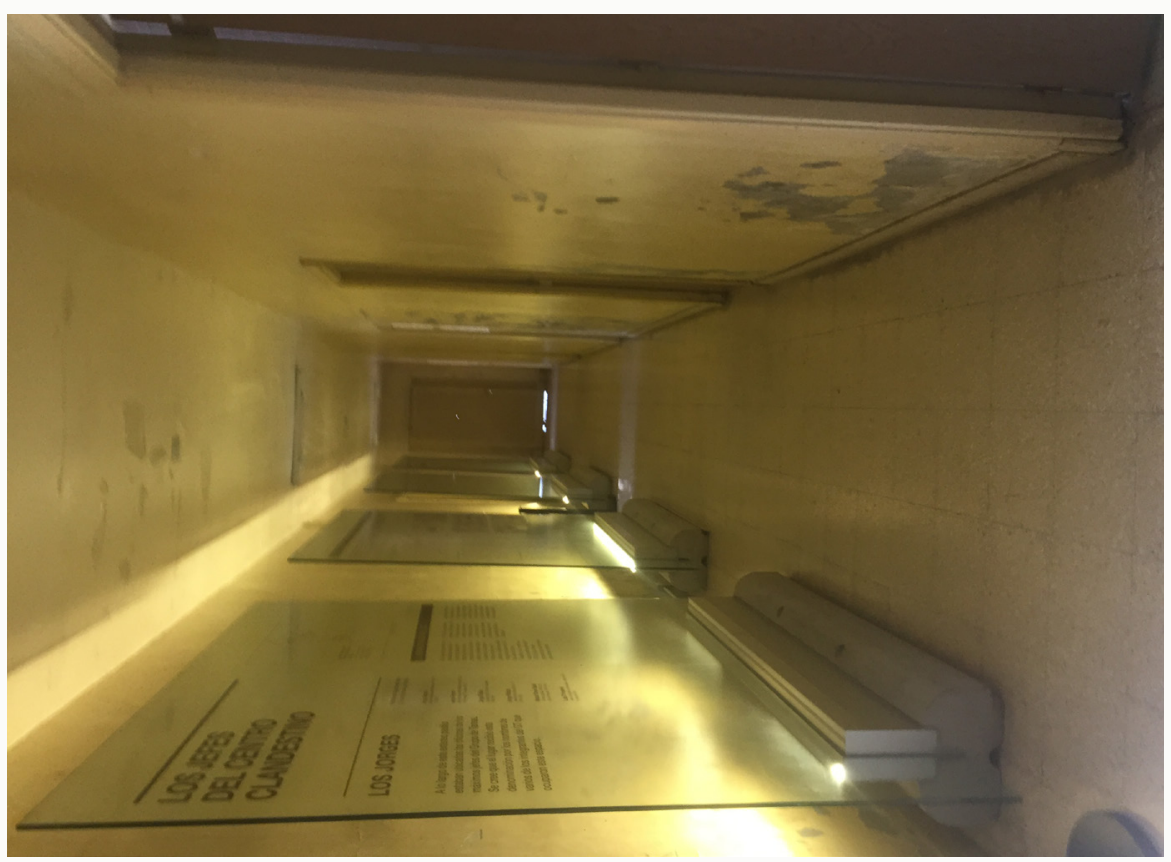

Fonte: Registro da autora, Buenos Aires, 2017.

Segundo Naftal, buscou-se fazer um museu "cômodo para o incômodo e incômodo para o cômodo", ao mesmo tempo convidativo e inquietante. Ainda nesse sentido, segundo ela, optou-se não por expor fotos, objetos e vídeos que explicitassem a violência, mas que mobilizassem o tema de forma leve mas, mesmo assim, comovessem o público. Afinal, ainda segundo a curadora, as pessoas que visitam esse tipo de museu buscam além de informações. Procuram experiências, caso contrário, bastaria recorrer a outras fontes.

Exemplo emblemático dessa opção são o segundo e o terceiro pontos altos do percurso, que acontecem respectivamente na sala em que permaneciam as grávidas e no subsolo.

Na sala das grávidas está exposta uma carta de Patricia Marcuzzo à sua mãe, na qual

9 Entrevista concedida por Alejandra Naftal à autora, em Buenos Aires, no dia 15/05/2018. 
descreve as características do filho Sebastian, que acabara de nascer no centro clandestino, na sala ao lado. Os torturadores obrigavam as vítimas a escrever cartas a seus parentes quando pariam, alimentando a esperança de retorno junto aos seus familiares e, assim, mantendo sua condição de desaparecidos. Mas, na grande maioria das vezes, nem as mães nem os filhos voltavam. Sebastian foi a única exceção, de uma criança entregue à família junto com a carta. A carta de Marcuzzo, remetendo a duas ações centrais - a de escrever e a de parir - que aconteceram ali, onde se pisa, torna impossível não tentar imaginar a cena. Aquelas linhas mal traçadas, difíceis de compreender, extrapolam o documento e completam aquele espaço repleto de ausências.

No segundo ponto alto estão as fotografias do informe Basterra, localizadas no sótão. Vitor Besterra, um dos presos políticos, fora incumbido pelos militares de falsificar documentos e fazer os registros dos detidos e dos próprios militares. Em certo momento começou a fazer cópias desses documentos, escondendo-os em uma caixa foto sensível, que os militares não abriam por medo de queimar os filmes. Nos últimos meses de detenção, logrou um regime de liberdade vigiada, quando pôde levar as cópias e guardá-las em sua casa. Em 1984, com o fim da ditadura, apresentou essa série de documentos no Juício a las Juntas, o que foi de grande importância para identificar os torturadores e os detidos. No museu, escolheu-se expor os retratos dos prisioneiros ao chegarem neste sítio, em um painel localizado na parede exata em que foram tiradas as fotos, nos levando novamente a imaginar as cenas que se passaram ali. Contudo, acima do painel há uma câmera de segurança do museu. Nesse momento do percurso, duas temporalidades distantes, do espaço como lugar da barbárie e do espaço como o lugar da cultura, enquanto museu, parecem se cruzar de alguma forma (Didi-Huberman, 2014).

Imagem 5 - Painel sobre o Informe Besterra

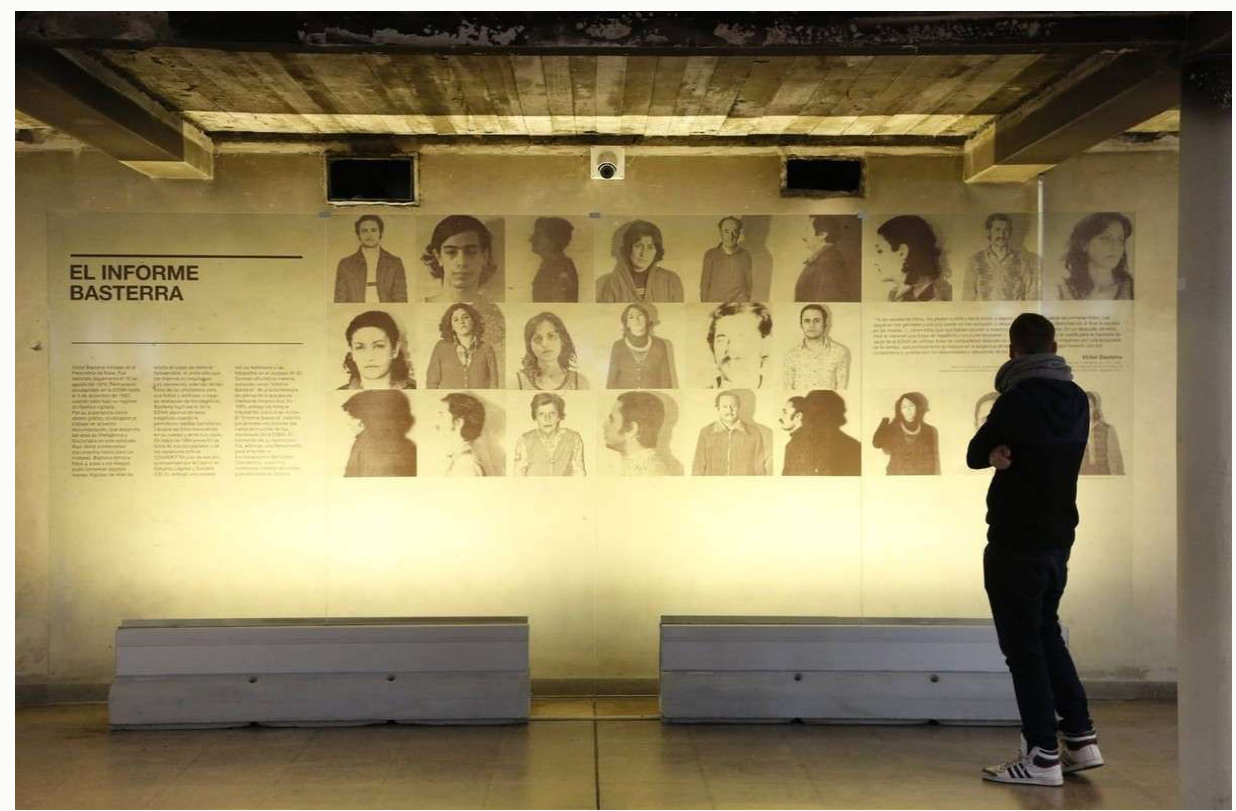

Fonte: Jornal El Clarín, abril de 2017. Disponivel em: https://www.clarin.com/politica/buscan-museo-ex-esma-patrimonio-cultural-humanidad 0 B1-p1-aCq.html> acessado em 15/05/2018. 
No sótão também existem algumas placas de acrílico, apoiadas nas vigas e paredes. Em uma delas, por exemplo, está escrito "Viga: é uma das primeiras recordações dos sobreviventes. Localizada no quarto que dava acesso ao sótão, de altura escassa, fazia com que os prisioneiros, com os olhos cobertos pelas vendas batessem a cabeça". ${ }^{10}$ Diferente dos dois momentos chaves, esse tipo de sinalização não está remetida a um personagem único, com uma história excepcional, mas à uma ação cotidiana, relatada por um conjunto de ex-presos.

Imagem 6 - Placa de acrílico sobre a viga

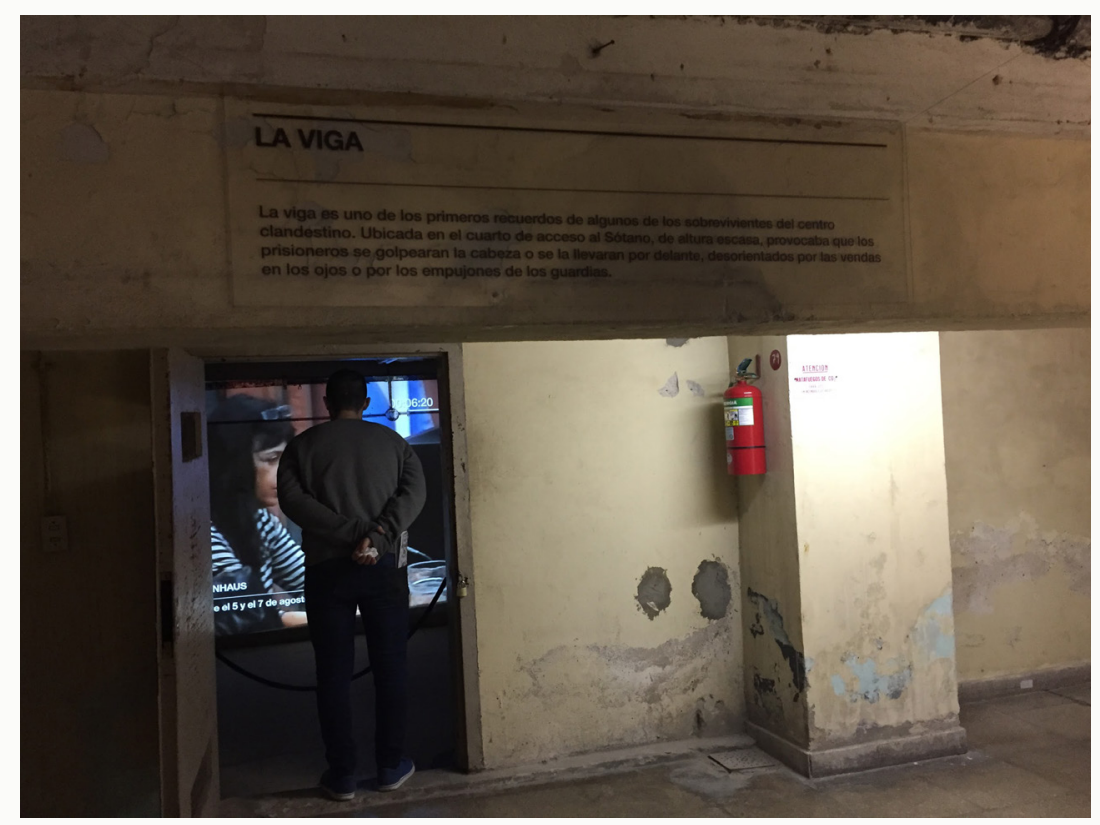

Fonte: Registro da autora, Buenos Aires, 2017.

A estação final, o Salón Dourado, usado pelos militares como depósito de arquivos e sala de reunião, constitui o último ponto alto da narrativa. Desta vez a intervenção é, mais que nada, teatral: lá os visitantes são convidados a sentar, as janelas se fecham, as luzes são apagadas e outro vídeo é projetado nas quatro paredes. São exibidos trechos dos julgamentos, fotos dos criminosos e a situação jurídica atual de cada um: "condenado", "não condenado", "na prisão". Ao final a janela se abre, apontando, assim como no começo do percurso, a luta e à uma vitória dos grupos de direitos humanos por meio da repetida consigna: 'memória, verdade e justiça'. 
Imagem 7 - Placa de acrílico sobre a viga

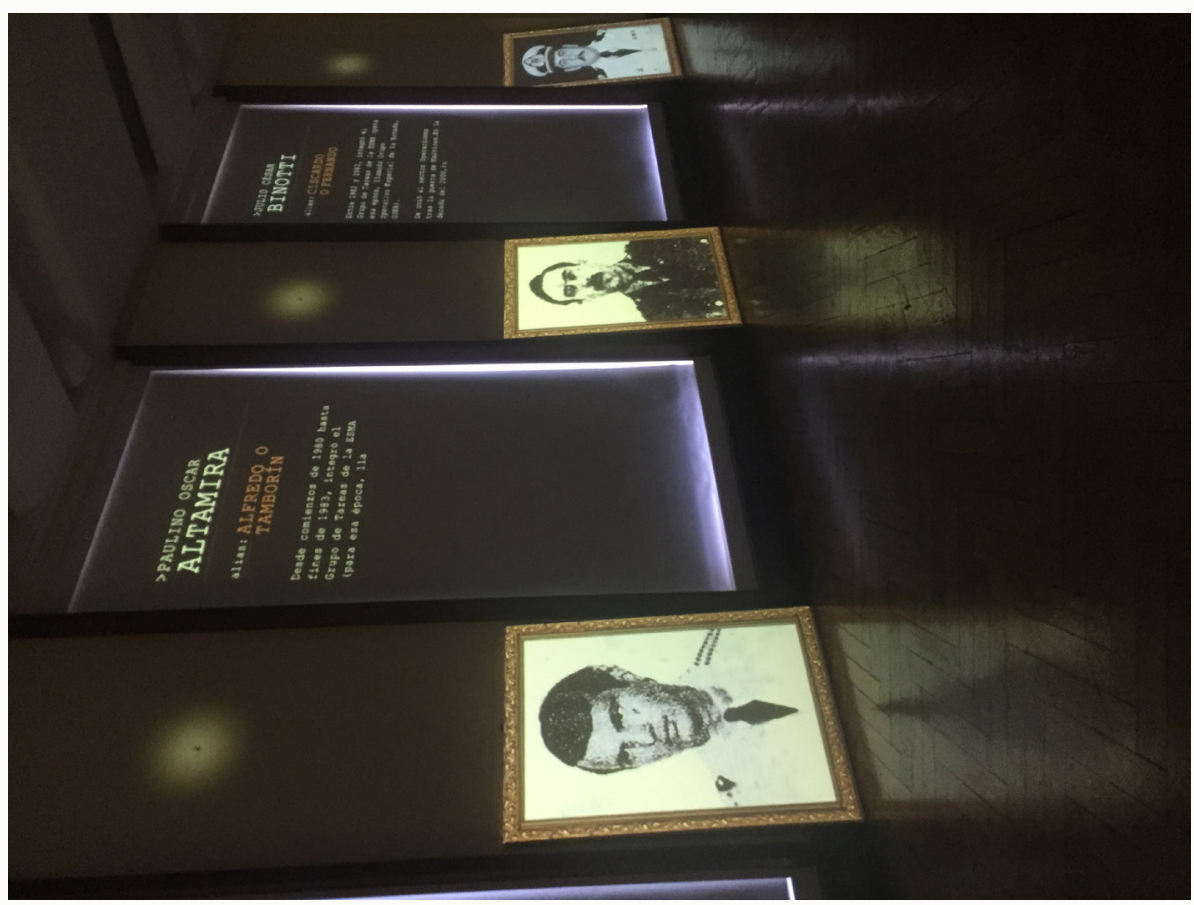

Fonte: Registro da autora, Buenos Aires, 2017.

A partir do percurso foi possivel identificar uma narrativa, composta por quatro momentos centrais: a introdução, onde se contextualiza a história da ditadura como um todo, chegando aos movimentos de direitos humanos; dois momentos inseridos no desenvolvimento, a carta de Marcuzzo e o informe Besterra; e o final, voltado à história e às conquistas da luta política. Todos esses pontos referem-se, em maior ou menor medida, a histórias excepcionais e vitoriosas, deixando em segundo plano o cotidiano dos desaparecidos, narrado por exemplo nas placas de acrílico apoiadas nas vigas e paredes. Embora essa narrativa demonstre uma tendência da luta política argentina ao deslocamento da figura das vítimas, estudantes e trabalhadores comuns como nós, ao papel de heróis - um movimento cuja as raízes encontram-se, em grande medida, na autoimagem épica construída pelas organizações de esquerda na ditadura (Vezzetti, 2001) - o que talvez promova um distanciamento entre o espectador e os personagens de sua história. Por outro lado, por essas vias, também se busca destacar a possibilidade de resistência e reação, frente às injustiças cotidianas, algo exigido por alguns atores sociais que participaram de sua construção. Deparamo-nos, portanto, com outro paradoxo: ao mesmo tempo que o museu foi construído pelos rastros e restos de uma história bárbara e pela vontade de mostrar esse passado; retoma uma construção da histórica típica do século XIX, linear e ascendente, apoiada em grandes feitos, personagens épicos e vitoriosos, deixando em segundo plano os fatos cotidianos que o construíram.

No museu, contudo, as razões disso parecem ir além das raízes da luta política dos movimentos de esquerda argentinos da década de 70. Dizem também respeito à vontade de construí-lo para um grande público. Afinal, apesar dos diversos movimentos das últimas décadas que buscaram e lograram iluminar histórias de violências (em seu sentido mais amplo) antes na 
penumbra, sabe-se que esse tipo de construção histórica está extremamente embrenhada na cultura ocidental e guia em muito nossas preferências. Nessa medida, poderíamos arriscar ainda outra hipótese: a própria escolha de um prédio do complexo da Ex ESMA, antigo, monumental e imponente, para abrigar um museu voltado ao grande público, passa em alguma medida também pela vontade de criar uma instituição com a qual o público se identifique. Dialoga com o próprio senso comum da noção de patrimônio, identificado como edifícios e artefatos belos, antigos e monumentais. (Smith, 2006), os quais constituem nossas preferências, tendendo a ser mais aceitos e apreciados pelas pessoas.

Imagem 8 - Vista afastada do Ex-Atlético

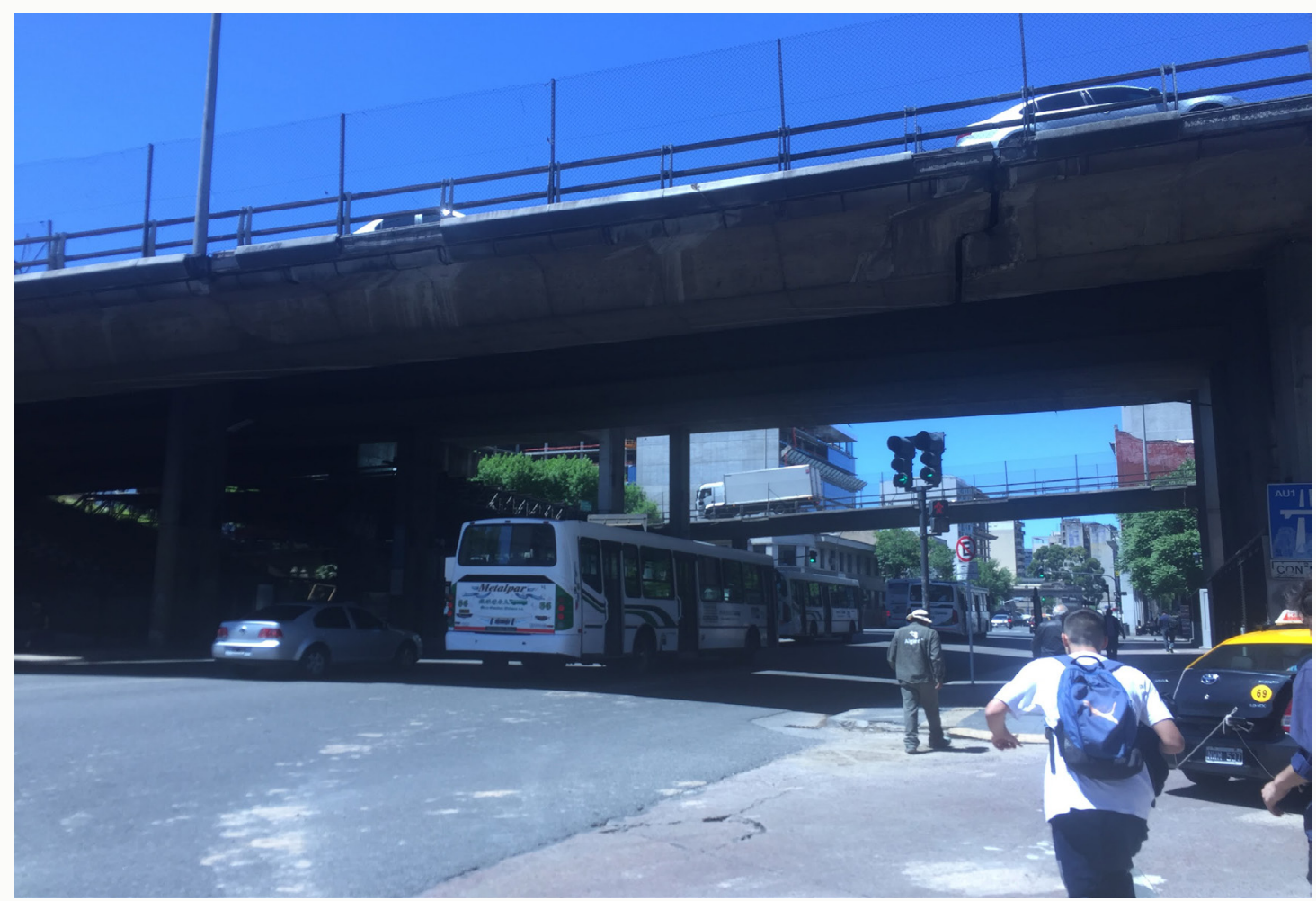

Fonte: Registro da autora, Buenos Aires, 2017.

Em contraposição ao caráter monumental da Ex-ESMA, os restos do Club Atlético não sobressaem na paisagem da cidade. Encontram-se abaixo do viaduto 25 de Mayo e abaixo do nível da rua e são apenas visíveis para os pedestres que passam por ali. Apesar deste posicionamento, o sítio encontra-se extremamente emaranhado na trama urbana. Localizase no bairro de San Telmo, na altura do número 1200 da Av. Paseo Colón, uma agitada e importante avenida, que corta o centro histórico de Buenos Aires. De um lado, onde ficava o centro, estão as escavações, um sítio arqueológico, protegido por uma grade; do outro uma praça, construída a posteriori da ditadura, em homenagem aos detidos desaparecidos; e, a duas quadras dali, há um laboratório dedicado aos trabalhos arqueológicos, no qual também estão expostas algumas das peças encontradas. $O$ trabalho de escavação vem acontecendo 
desde 2002; em 2003, o governo nacional criou o Programa de Recuperación de la Memoria do Centro Clandestino de Detención 'Club Atlético', junto a ele, a Comisión de Trabajo y Consenso ${ }^{11}$; e, em 2014, o sítio foi declarado patrimônio histórico nacional. Hoje suas atividades são coordenadas pela Mesa de Trabajo y Consenso e pelas arqueólogas Silvina Duran e Laura Dúguine.

Durante a ditadura o centro de detenção estava instalado em um edifício de três andares, sede do Servicio de Aprovisionamento y Talleres da divisão administrativa da polícia federal. Nos primeiros andares aconteciam as atividades legais, e no subsolo as práticas comuns aos centros clandestinos de tortura e encarceramento dos presos políticos. Em apenas um ano de funcionamento (1977), passaram 1500 presos políticos. Como afirma Juan Batle ${ }^{12}$, vizinho do Atlético, "quando alguém caminhava casualmente, encontrava caminhões que descarregavam produtos de papelaria, máquinas de escrever, um movimento normal". No entanto, diversas pessoas, que anos mais tarde concederam depoimentos à Justiça, afirmavam que, a partir do golpe de 1976 costumavam ouvir ruídos e gritos durante a noite ${ }^{13}$. No final de 1977, o local foi destruído, para dar lugar ao viaduto 25 de Mayo. Os presos do Atlético foram levados primeiro ao Banco e depois ao Olimpo. Mas, além disso, a construção do viaduto implicou em um processo violento de desapropriação dos cortiços da região, gerando grandes vazios em seu entorno ${ }^{14}$.

11 A mesa de trabalho e consenso foi criada pelo governo federal em 2003 para todos os sítios de memória que vinham sendo criados nesse momento. Tratam-se de grupos compostos por membros de organizações de direitos humanos, envolvidos nas lutas de cada sítio, vítimas e parentes de vítimas, que ficam encarregados por desenvolver as atividades em cada lugar.

12 Entrevista de Juan Batle ao documentário "Espacios de Memoria - Club Atlético" (25 min.) produzido pelo Canal Encuentro, Buenos Aires, 2014, 5'.

13 Esses depoimentos estão disponíveis no documentário 'Espacios de Memoria - Club Atlético' realizada pelo Canal Encuentro em 2014. Disponível em: https://www.youtube.com/watch?v=dXjz-ax_jfQ\&t=343s>. Acessado em 15 de maio de 2018.

14 Dessa forma, tanto as práticas repressivas no interior do Atlético; quanto os processos de 'revitalização' de seu entorno, que começaram nessa época, revelavam o ímpeto violento e excludente do processo de reorganização nacional proposto pelos militares. Buscava-se aniquilar qualquer "empecilho". Sejam eles os militantes de esquerda, que lutavam por uma sociedade democrática; sejam apenas pessoas pobres que pareciam 'sujar' a cidade aos olhos dos militares, indo contra a cidade limpa e ordenada imaginada pelos militares. 
Imagem 9 - Construção da Autopista sobre o Club Atlético em finais de 1979

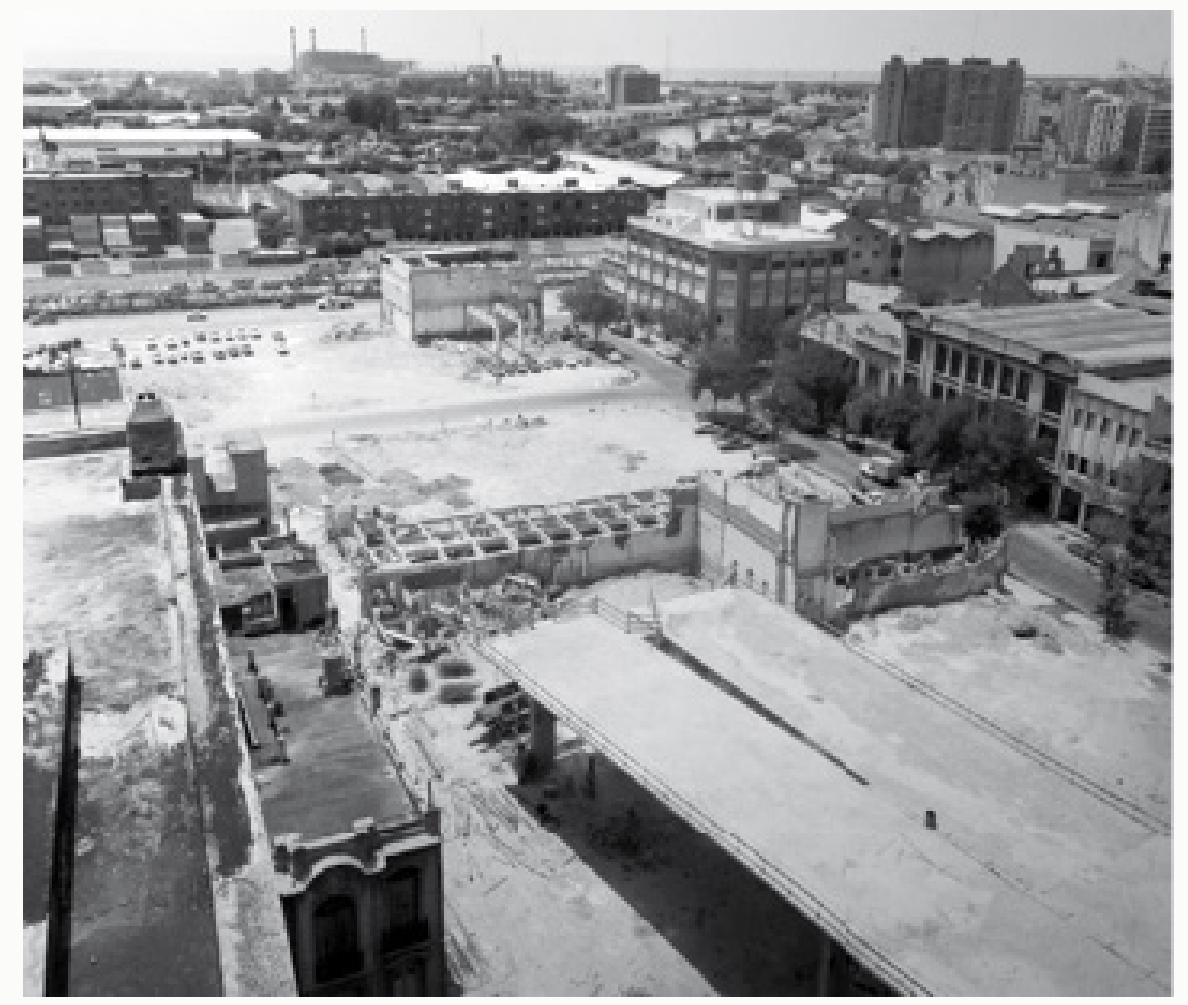

Fonte: Arquivo concedido pelo Sítio de Memória y Promoción de los Derechos Humanos Club Atlético.

O ambiente do Atlético parece ser resultado desse processo. Como a maioria dos espaços localizados embaixo de viadutos é úmido, escuro e barulhento. O sítio, por sua vez, está completamente em ruínas, mais do que os outros centros clandestinos, o que dificulta entendimento de sua espacialidade original. Nesse sentido, as visitas são sempre guiadas e, no começo do percurso, recebe-se um folheto com uma maquete virtual, que explica a função de cada ambiente. Assim, a explicação do espaço é sempre mediada pelo discurso de um guia e da maquete virtual exposta em um folheto.

Apesar da dificuldade, é possível enxergar no primeiro andar os restos de um piso azulejado; e, no subsolo, algumas celas para incomunicáveis, uma sala de tortura e outra usada para enfermaria, o setor para depósito dos pertences dos detidos, parte dos dois setores de celas, que se sabe a partir dos depoimentos que somavam 41, parte das salas de tortura e um elevador que dava acesso ao piso superior. De muitas paredes só restaram marcas, outras estão pela metade; e outros locais ainda não aparecem por completo, pois estão embaixo da terra. Além disso, existem muitos aparatos para o trabalho arqueológico: madeiras, andaimes, marcações. Desse modo, o sítio configura-se ao mesmo tempo como sítio arqueológico e canteiro de obras, como passado e futuro (Taylor, 2009). 
Imagem 10 - Interior do sítio arqueológico

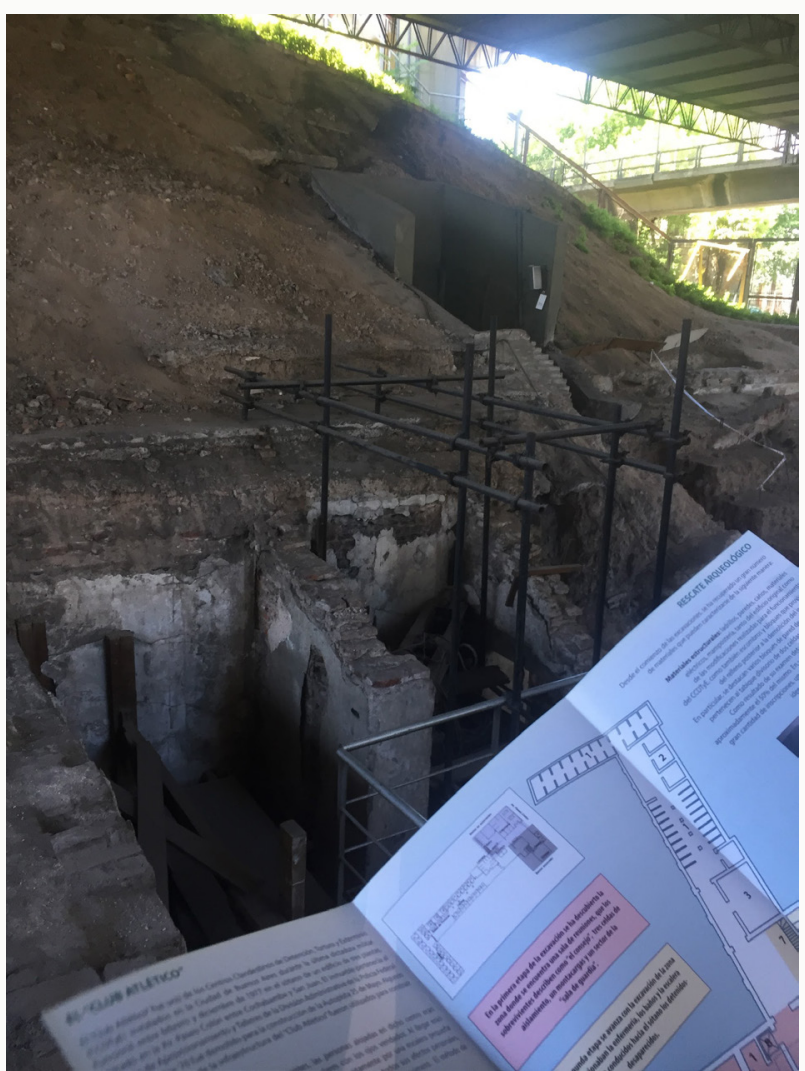

Fontes: Registro da autora, 2017

Nesse caso em que não há museu, mas um sítio arqueológico, notam-se diversas sinalizações, no talude que apoia a autopista, em seus pilares e nas grades de proteção do sítio. Algumas foram claramente implantadas pelo Estado, são azuis e brancas, e carregam o logotipo do governo: tratam-se de maquetes virtuais com depoimentos que explicam cada ambiente do espaço original; placas explicativas da história do sítio; ou placas que sinalizam sua condição de patrimônio histórico. Explicam os quem, por quê, onde e quando (Taylor, 2009). Já outras, mais complexas e diversas, implantadas pelos movimentos sociais, são comemorativas e reivindicativas. Dizem "30.000 companheiros desaparecidos", "Memória, verdade e justiça", "Julgamento e Castigo", "Não ao esvaziamento da memória". Um pouco mais afastadas, em placas amarelas, estão as propagandas das obras públicas do governo, comuns a toda cidade.

O conjunto de sinalizações, estatais ou não, parecem operar como camadas históricas do processo de memorialização do local, o que se evidenciou por meio de conversa com Suzana Mitre, ex-vizinha do Club Atlético, e com Silvina Duran, uma das arqueólogas responsáveis pelas escavações.

Mitre, falando em terceira pessoa, introduziu a história da recuperação do centro, 
pelos grupos de direitos humanos. Assim como nos outros sítios, diz que foi um longo caminho de luta. Começou com as denúncias individuais dos sobreviventes e vizinhos, logo no fim da ditadura; passou por movimentos de visibilização, como Escraches e Jornadas de Memória, nos anos 90; e, finalmente, com a entrada de Nestór Kirshner no poder, nos anos 2000, e uma intervenção mais incisiva do Estado, tornou-se possivel o início das escavações e sua transformação em um sítio de memória e promoção dos direitos humanos. Mitre reforça que, para ela, a importância do local sempre consistiu em seu caráter de prova jurídica dos crimes.

Ainda falando sobre o processo de memorialização do centro clandestino, Suzana Mitre aponta duas sinalizações presentes no sítio: uma grande silhueta sobre o talude de terra, contornada por tijolos e tochas, ao lado de placas com os nomes dos desaparecidos; e o pilar da autopista, repleto de figuras humanas sem rostos e de metal. Ambas as intervenções foram gradativamente elaboradas por vizinhos, familiares e ex-detentos do Club Atlético durante as Jornadas por la Memória. Uma série de encontros ocorridos entre 1996-2000, onde militantes populares inseridos em organizações de bairro - em sua maior parte familiares, sobreviventes e organismos de direitos humanos - se uniam para elaborar intervenções artísticas e outras formas de sinalização que iluminassem a existência do sítio na cidade, em um momento em que todavia os ex CCDTyE ainda passavam desapercebidos ${ }^{15}$.

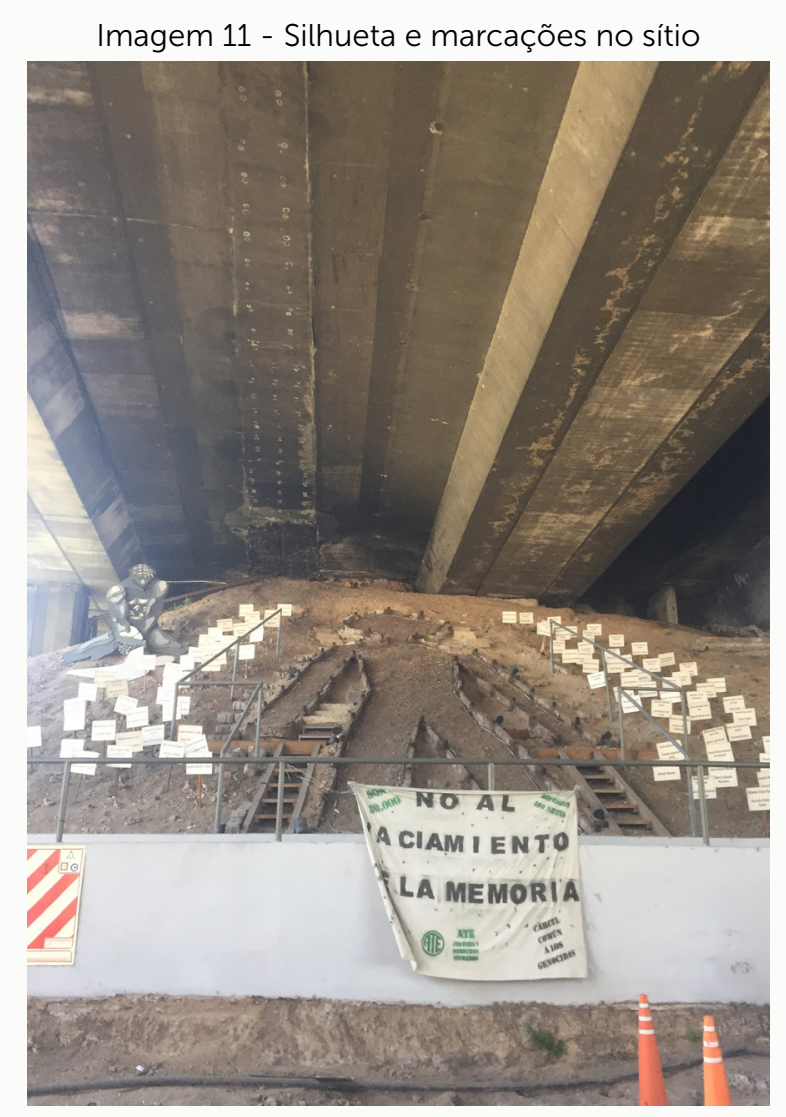

Fontes: Registro da autora, Buenos Aires, 2017. 


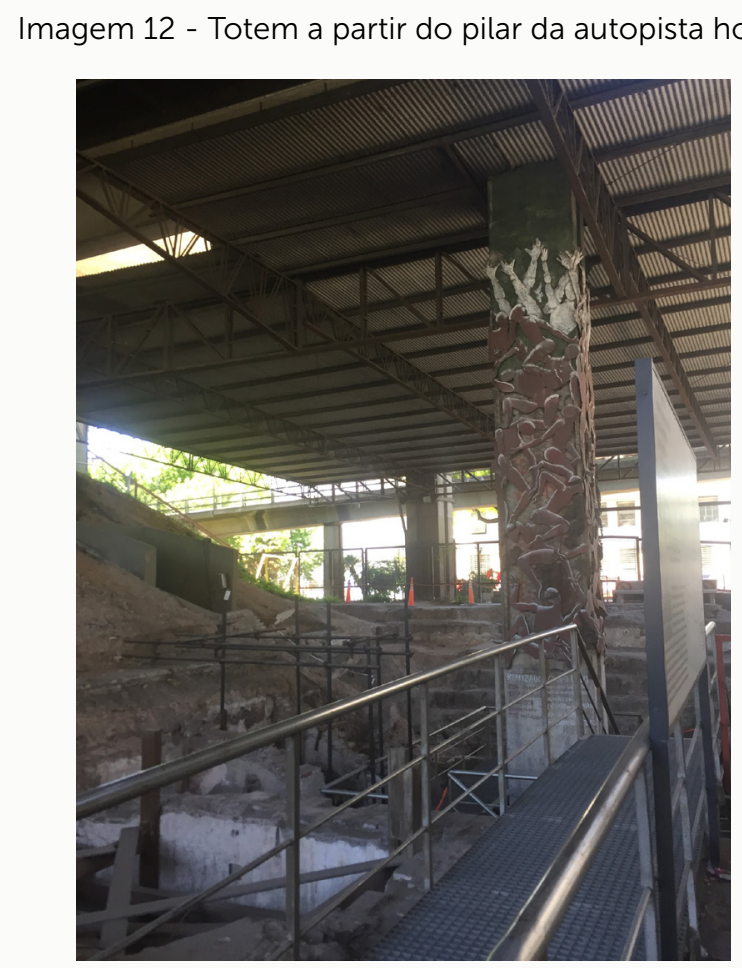

Fonte: Registro da autora, Buenos Aires, 2017.

Imagem 13 - Sinalizações no sítio

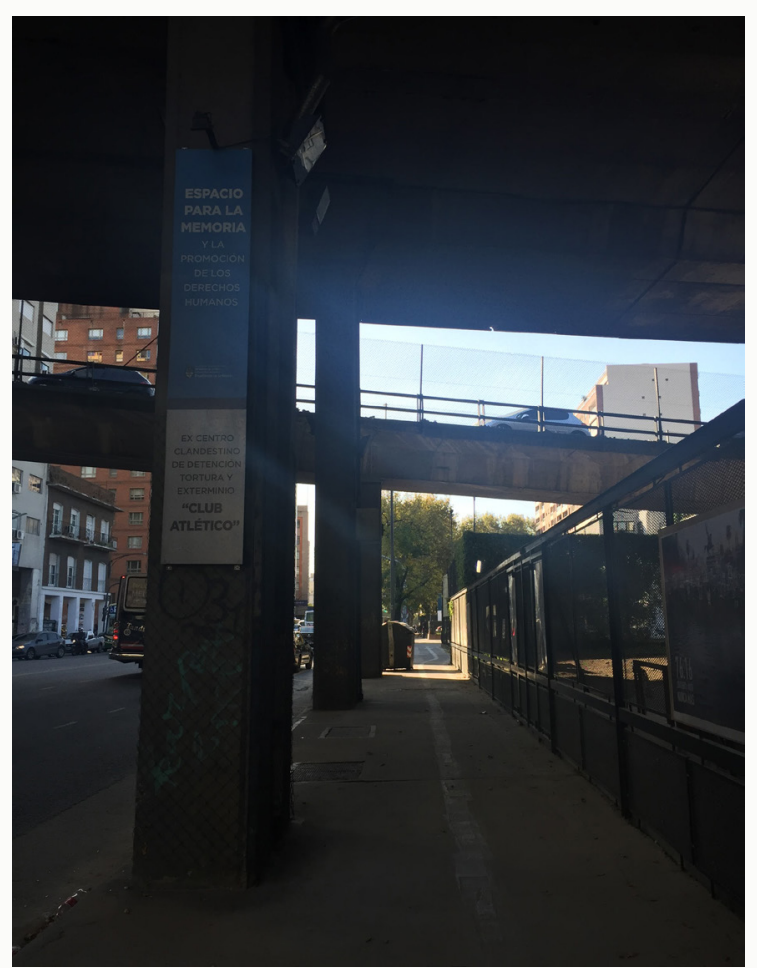

Fonte: Registro da autora, Buenos Aires, 2017.

Na primeira jornada, em 1996, foi produzido o totem a partir do pilar da autopista, colocados faixas e cartazes de reivindicação, e espalhados os nomes dos torturadores pelo 
espaço. Em sua primeira versão, o totem era uma árvore desenhada no pilar, com esculturas de papel machê coladas. Eram corpos desfigurados, vendados, que representavam a situação e as agonias que os desaparecidos passaram no local. Contudo, horas após o fim do evento, as figuras de papel apareceram queimadas e os nomes dos torturadores cobertos. Como forma de resistência, uma semana depois, foi organizada a segunda Jornada por la Memória, onde as organizações refizeram o totem e acrescentaram a silhueta de pedra no talude que cobria os escombros.

Imagem 14 - Primeira Jornada por la Memoria no Club Atlético, 1996

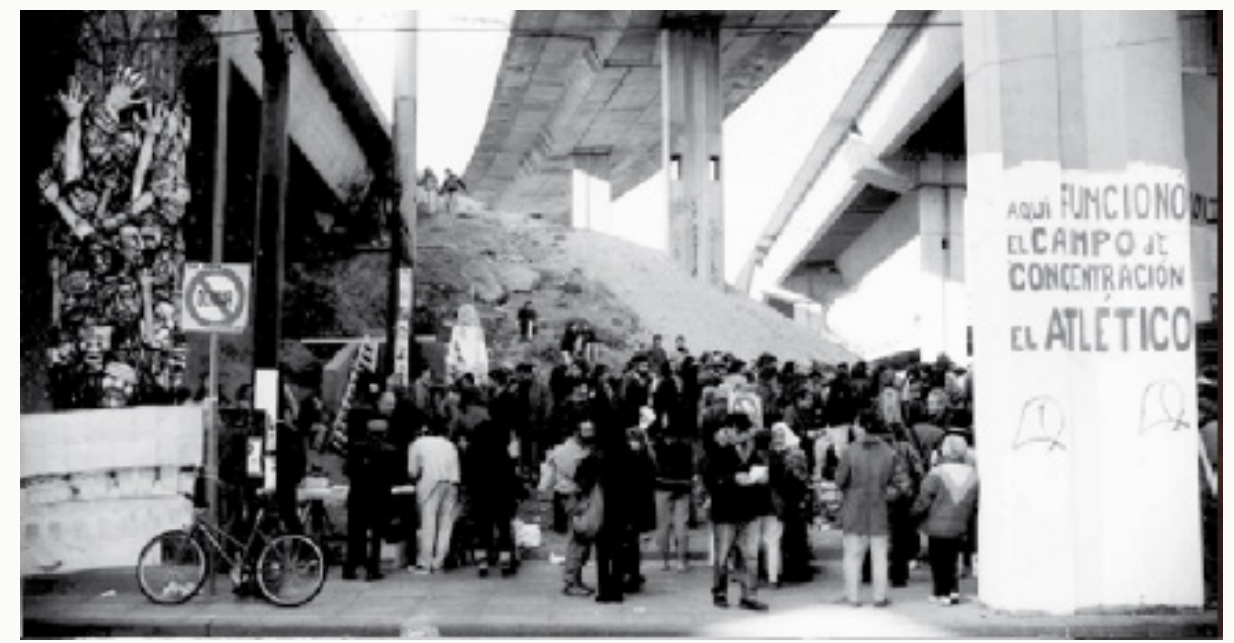

Fonte: Arquivo concedido pelo Sítio de Memória y Promoción de los Derechos Humanos Club Atlético.

Imagem 15 e 16 - Destruição do primeiro grupo escultórico construído na primeira Jornada por la Memoria - Club

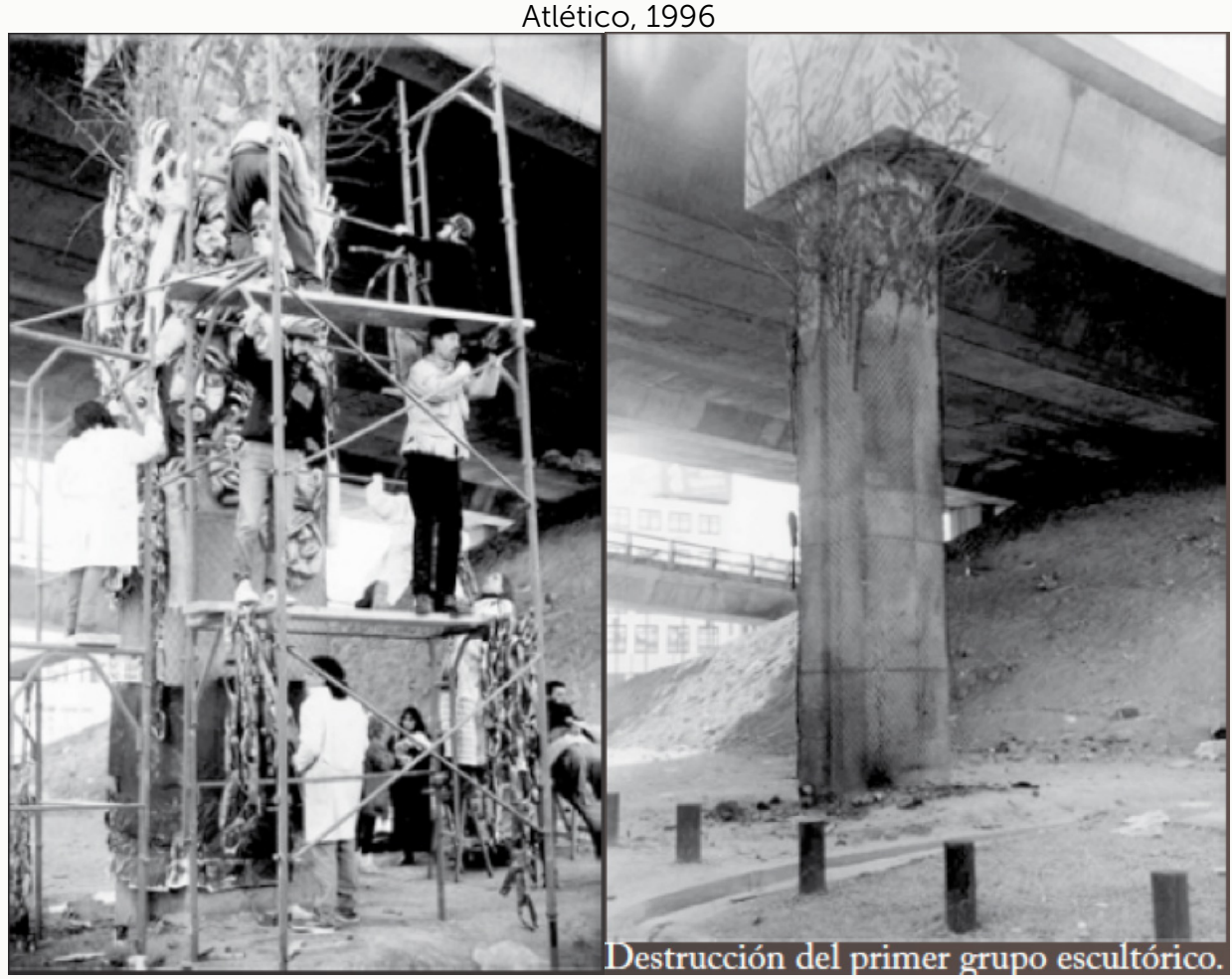

Fonte: Arquivo concedido pelo Sítio de Memória y Promoción de los Derechos Humanos Club Atlético. 
Segundo Mitre, para evitar outro episódio desse tipo, os elementos foram mudando ao longo do tempo. As figuras no pilar, antes de papel machê, foram refeitas de madeira e, na terceira jornada, em 2000, novamente reelaboradas em metal. Já a silhueta, antes de madeira, também foi refeita na terceira jornada. Assim, hoje, enquanto o totem é composto por figuras de corpos inteiros em movimentos, sem rostos ou expressões faciais; a silhueta antes de pedra, agora é de tijolos, possui uma escada ao lado e, no talude, foram cravadas placas com os nomes dos desaparecidos. Todo o dia 24 de março, no aniversário do golpe, as Madres sobem pelas escadas e acendem as tochas da silhueta. Esta, ao mesmo tempo em que representa a presença dos desaparecidos pelo seu contorno, também representa a ausência de cada um deles, por seu vazio ${ }^{16}$. Desse modo, tanto as sinalizações quanto as considerações apresentadas por Mitre apontam a necessidade de entender os sítios estudados como objetos em constante movimento, sujeitos a mudanças e ressignificações que acompanham os desejos e as demandas do presente.

Nesse mesmo sentido, observou-se que o entorno do ex-Atlético vem sofrendo diversas alterações e, como o próprio sítio, também parece um canteiro de obras. Trata-se de um conjunto de obras públicas que busca 'revitalizar' a área de San Telmo, um bairro histórico e turístico de Buenos Aires. Uma estratégia muito comum aos centros urbanos contemporâneos, onde se busca, em última instância, embelezar e modernizar a região, para torná-la mais atraente ao capital internacional.

Este processo, que vem se acelerando no bairro, parece ter origem na ditadura militar. Se, por um lado, durante a ditadura, o governo financiava obras urbanas de caráter 'arrasa quarteirão', como foi o caso da autopista 25 de Mayo, que destruiu o Atlético e parte de seu entorno, visando também construir uma imagem de cidade moderna para ser mostrada na Copa do mundo de 1978; deve-se ter em vista que, no mesmo ano, o bairro de San Telmo foi tombado como patrimônio histórico. Assim, como nota Andrián Gorelik (2011, p.182), apesar do ímpeto destruidor dos militares, nessa época "comenzó el actual prestigio social de la conservación histórica en la ciudad [...] Hasta llegar al rol espectacularizador y mercantil de la memoria urbana en los discursos urbanísticos recientes". Em um movimento semelhante ao que proporcionou a condição do Club Atlético enquanto sítio arqueológico, além do processo clássico de gentrificação, que implica na expulsão dos moradores que não suportaram o aumento do aluguel, o próprio sítio de memória, por sua localização central na Paseo Colón, sofreu ameaças de apagamento, o que exigiu novas respostas da instituição.

Houveram dois casos recentes. O primeiro refere-se ao projeto de construção de trilhos para o Metrôbus na Av. Paseo Colón, anunciado em 2013 pelo então prefeito da cidade

16 O símbolo [da silhueta] surgiu como símbolo central na luta política a partir da intervenção artística Siluetazo, que aconteceu pela primeira vez em 1983, na Plaza de Mayo. Nesse momento, com a cidade ainda em clima de repressão os manifestantes pintaram, se deixaram desenhar e desenharam as silhuetas uns dos outros, para depois pregar 30.000 nos edifícios e árvores da Plaza de Mayo. Um símbolo genérico, fácil de ser desenhado e a princípio sem identificação que representava, ao mesmo tempo, cada desaparecido e o conjunto dos desaparecidos (Longoni y Bruzzone, 2008). Ao mesmo tempo suas presenças, afirmada pelo contorno dos corpos e pela própria ação; e suas ausências, afirmada pelo vazio do interior da figura. No Atlético, ele foi apropriado e ressignificado. Enquanto aquela única silhueta parece remeter à totalidade de vítimas, as placas remetem à cada um dos indivíduos. Adquiriu, além disso, um caráter ritualístico e comemorativo extremamente importante, ao mesmo tempo que trazem movimento, vida, ao sítio, ao acenderem o fogo e reunir a comunidade, a ação lembra um ritual fúnebre. Lá as placas cravadas na terra parecem atuar como lápides cemiteriais às quais acendemos velas. 
Mauricio Macri. Para a efetivação do projeto, a prefeitura previa derrubar imóveis em seis quadras, entre a Rua Carlos Calvo e Martín Garcia, incluindo o memorial do Club Atlético. Frente à proposta, o advogado do Centro de Estudios Legales y Sociales (CELS) entrou com um recurso argumentando que, desde 2005, o sítio está tombado como patrimônio histórico por sua condição fundamental de prova dos julgamentos em curso. Aprovado o recurso, o governo federal interveio, impedindo a construção dos trilhos naquele lugar.

O outro caso refere-se ao projeto do Paseo del Bajo, um viaduto que ligaria a Av. Riberiña, ao Viaduto 25 de Mayo, cuja licitação foi lançada em 2016 e avaliada em 650 milhões de dólares. Segundo a Mesa de Trabalho e Consenso ${ }^{17}$ do Ex- CCDTyE, a obra implicaria em demolições, execuções de base, movimentos de solo que afetariam diretamente o centro clandestino ${ }^{18}$. Acrescente-se que a licitação publicada pela empresa responsável nem sequer mencionava sua existência, o que levou a Mesa de Trabalho e Consenso, junto a trabalhadores, familiares e organizações de direitos humanos, à declarar um alerta amarelo. A partir disso, iniciaram uma campanha para que o sítio fosse considerado no projeto, e exigiram a formulação de uma circular pela empresa que mencionasse explicitamente as leis patrimoniais que o protegem. $\bigcirc$ pedido também foi acatado e a empresa produziu a circular demandada.

Por outro lado, também existem obras de melhoramento do próprio sítio. Como mencionou Ariel Gomplewicz, atual coordenador da Dirección Nacional de Sítios de Memoria ${ }^{19}$ há uma previsão de retirada do talude abaixo da autopista, para dar continuidade às escavações do sítio; e a construção de um edifício ao lado do sítio arqueológico, que abrigará um laboratório, os objetos encontrados e salas para realização de atividades educativas. Sobre o tema, Silvina afirma tratar-se de algo há muito tempo necessário, pois a infraestrutura para abrigar os objetos e realizar as atividades é muito precária. Contudo, não se deve deixar de lado que, enquanto uma grande obra pública, também cooperaria para agregar valor para aquela região, operando analogamente aos outros projetos de melhoramento.

A partir das considerações apresentadas, observam-se diversas frentes de análise, a partir do Club Atlético. Entretanto, pensando-o em relação a outros sítios de memória, como propõe a dissertação, notam-se algumas especificidades centrais, que estabelecem uma diferenciação em relação ao outro caso apresentado. Diferente do Museu de Sítio ESMA, a partir do qual foi construída uma narrativa mais clara e linear, com começo meio e fim; a materialidade do Ex-Atlético é apresentada de forma mais crua e complexa. Dado que o espaço está em ruínas, demanda mais esforço para compreender como era, enquanto centro clandestino. Por sua situação urbana - dado que está inserido em um ambiente extremamente ruidoso, escuro e úmido - torna-se, sem dúvida, menos confortável para o visitante e mais suscetível às dinâmicas mercantis da cidade contemporânea. Contudo, estes dados não são aqui considerados como defeito. Por ter se conformado ora como um vazio e por estar extremamente embrenhado na vida urbana da cidade, abre-se mais à cidade e a outras de

17 Trata-se de um grupo composto por militantes e representantes de organizações de direitos humanos responsável pela coordenação do sítio.

18 https://www.tiempoar.com.ar/articulo/view/61542/un-ex-centro-clandestino-corre-peligro-por-una-obra-dela-ciudad> acesso em 30 de dezembro de 2017.

19 Entrevista concedida por Ariel Gomplewicz à autora, em Buenos Aires, no dia 12/11/2017. 
memorialização. Em relação ao ambiente museológico da Ex-ESMA, parece incidir com maior força no cotidiano dos habitantes que ali transitam, os quais, vendo aquele local, talvez se perguntem do que se trata, e por que aquelas sinalizações se encontram ali.

\section{Considerações finais}

Nesse relato busquei delinear duas possibilidades distintas de representação da memória pelo espaço. Um primeiro caso de um sítio que tende mais a um museu, o Ex-Casino de Oficiales; e um segundo caso, de um sítio que tende a um sítio arqueológico. São dois espaços que, guiados principalmente por sua condição história, desempenham diferentes papeis na topografia de dor da cidade.

No primeiro caso, a ideia de criação de um museu no Casino de Oficiales foi e ainda é sistematicamente criticada por alguns grupos de direitos humanos e atores sociais. Estes criticam tanto uma possível 'banalização da memória', por sua inserção em um roteiro turístico (Guglielmucci, 2011); quanto, como mencionou uma das conservadoras do espaço em uma conversa informal, sua alteração visual por meio de intervenção museológica, o que dificultaria o reconhecimento do sítio pelas vítimas ${ }^{20}$.

Certamente sabe-se do potencial turístico dos museus nas cidades contemporâneas, o que pode acarretar em incômodos compreensíveis por aqueles que possuem alguma vinculação com o local. Sabe-se também que a remodelação em memoriais e museus a favor da autenticidade significa, inevitavelmente, uma perda de autenticidade - pois é sempre necessário selecionar o acervo, acrescentar aparatos museológicos ou fazer obras de conservação que alteram o espaço (Assman, 2011). Entretanto, considero que o caráter de museu apresenta outras vantagens: coopera tanto para a visibilidade da história da ditadura militar argentina na esfera global, algo desejável para uma ampliação da consciência política; quanto para a criação de uma narrativa coesa e legível para qualquer um que visite o país.

Dessa forma, o Museu de sítio ESMA adquiriu um papel chave e específico na topografia de dor de Buenos Aires: o de anunciar a questão. O Club Atlético, diferente do museu, parece atuar com maior ênfase no âmbito local e na escala do bairro, especialmente por sua condição urbana. Se, por um lado, tal condição traz vantagens, pois assim ele abre-se mais à cidade e às diversas possibilidades de memorialização. Por um lado, na medida em que seu entorno vem passando por diversas obras de melhoramento, tal condição levou-o a constantes ameaças de apagamento, trazendo à tona impasses urbanos análogos aos que o atingiram durante a ditadura. Além disso, note-se que os trabalhos arqueológicos lá desenvolvidos, apesar das dificuldades com infraestrutura, tornaram-se exemplos emblemáticos para a área da arqueologia urbana no país. As arqueólogas responsáveis não apenas trabalham no Ex-Club Atlético, mas prestam assistência a outros centros clandestinos argentinos. Desse modo, sua própria condição de

20 Como afirma Aleida Assaman (2011), a remodelação em memoriais e museus está sujeita a um paradoxo profundo: a conservação desses lugares a favor da autenticidade significa inevitavelmente uma perda de autenticidade. Para realizar um projeto museológico, é necessário selecionar o acervo, o que implica exclusão de grande parte; e, por vezes, as obras de conservação no local substituem e alteram o espaço original. 
sítio arqueológico operou também como um dispositivo para o desenvolvimento de áreas do saber extremamente preciosas para operar com sítios semelhantes.

Não podemos deixar de lado, também, a guinada política da direita em quase todos os países latino-americanos, que vem afetando diretamente as políticas de direitos humanos desenvolvidas nesses contextos. Na Argentina, como apontou a grande maioria dos agentes institucionais dos sítios, algumas questões que pareciam resolvidas reapareceram recentemente. Em 2016, o governo federal começou a questionar a cifra simbólica consolidada na luta política por grupos de direitos humanos de 30.000 desaparecidos, afirmando que constavam formalizadas 8.571 vítimas; discutiu se a ditatura foi militar ou cívico-militar, bem como propôs a redução da pena dos condenados pelos crimes ditatoriais pela metade, por meio de uma lei denominada 2x1 (Jelin, 2017). O conjunto de ações exigiu novas respostas dos sítios de memória que, novamente, buscaram caminhos para sobreviver às mudanças política. Para tanto, seja no Ex-Atlético ou na Ex-ESMA, nota-se a constante preocupação de realizar atividades educativas e comemorativas, capazes de envolver e ampliar a consciência política do maior número possível de pessoas. O Museu de Sítio, além disso, recentemente logrou ser lançado como candidato a patrimônio cultural da humanidade pela UNESCO que, caso aprovado, seria uma mais uma garantia de preservação, que reforçaria a lei patrimonial nacional que já o protege.

Assim, se por um lado o trabalho de campo permitiu a aproximação com os objetos de estudo, com os atores sociais que os constroem e o levantamento de documentos relativos aos cinco sítios; por outro lado demandou o desenvolvimento de novas ferramentas de análise, dada a dificuldade de descrevê-los e a ampla gama de caminhos passíveis de serem seguidos na dissertação, com os quais me deparei nesse período. Afinal, ao fim e ao cabo, não são apenas museus, só memoriais ou sítios arqueológicos, mas adquirem múltiplos sentidos e significados: para os que lá viveram, podem ser lugares de um trauma partilhado; para os parentes das vítimas podem ser cemitérios; para os que não têm vinculação com a história, podem ser apenas museus; para os chefes de Estado tornam-se, muitas vezes, palco para pronunciamentos públicos; e para a justiça são provas dos crimes (Assmann, 2011).

Verificando a quantidade de informações presentes nos lugares físicos, que não se encontram em livros, filmes ou fotografias, aprendi que era necessário gastar tempo nos lugares, visitá-los diversas vezes, caminhar por seus arredores, perceber suas paisagens sonoras e conversar com as pessoas que os constroem no seu dia-a-dia, incorporando essas vozes à análise a ser por mim construída por mim. Trata-se de um dado importante, uma vez que não tenho qualquer vínculo pessoal ou familiar com esses sítios e suas histórias.

Nesse sentido, cada vez mais foi se confirmando que, para analisá-los em rede buscando responder como eles constroem (ou não) uma narrativa complexa e não redundante na cidade - obtemos maior rendimento entende-os como um corpo múltiplo, internamente tenso e em constante movimento, e não como um bloco unívoco que, em última instância, só se constrói quando tomado por oposição a alguma coisa - autoritarismo, neoliberalismo, conservadorismo, governo Macri, etc. Embora partam de uma história comum - as violências cometidas na ditadura militar - , em cada um são expressas diferentes temporalidades, disputas e vontades, que põem à prova no espaço público as memórias e os desejos mais profundos das 
pessoas envolvidas nos processos de luta (Di Cori, 2005).

\section{Referências bibliográficas}

ASSMANN, Aleida. Espaços da recordação. Campinas: Editora da Unicamp, 2011. 456p.

DI CORI, Paloma. La memoria pública del terrorismo de estado. Parques, museos y monumentos en Buenos Aires. En: ARFUCH, Leonor. Indentidades, sujetos y subjetividades. Buenos Aires: Prometeo libros, p. 91-112, 2005.

DIDI-HUBERMAN, Georges. Cortezas. Santander: Shangrila, 2014. 72p.

DIÉGUEZ, Ileana. Cuerpos sin duelo: Iconografías y Teatralidades del dolor. Córdoba: Ediciones Documenta/Escénicas, 2013. 292p.

DOLFF-BONEKÄMPER, Gabi. Sites of Hurtful Memory. Conservation: The Getty Conservation Institute Newsletter. Los Angeles, v. 17, n. 2, p. s/p, 2002. Disponível em: <http://www.getty.edu/ conservation/publications_resources/newsletters/17_2/feature.html>. Acesso em 15/05/2018.

FEIERSTEIN, Daniel. Genocide as social practice: reorganizing society under the Nazis and Argentina's military juntas. New Jersey: Rutgers University Press, 2014. 276p.

GORELIK, Adrian. La memoria material: Ciudade Historia. Boletín del Instituto de Historia Argentina y Americana Dr. Emilio Ravignani. Buenos Aires, n. 33, p. 181-187, dez. 2011. Disponível em: $<$ http://www.scielo.org.ar/scielo.php? script=sci_arttext\&pid=S0524-97672011000100026>. Acesso em 15/05/2018.

GUGLIELMUCCl, Ana. El proceso de consagración de la memoria del terrorismo de Estado como política pública estatal de derechos humanos en Argentina. Tesis (Doctorado en Historia). Faculdad de Filosofía y Letras, Universidad de Buenos Aires, Buenos Aires, 2011. 388p.

HUYSSEN, Andreas. Mapeando o Pós-Moderno. In: Pós-modernismo e política. Rio de Janeiro, Rocco, 1991. 237p.

Seduzidos pela memória. Rio de Janeiro, Aeroplano, 2000. 116p.

Present Pasts: Urban Palimpsests and the Politics of Memory. Satanford, Stanford University Press, 2003. 177p.

Culturas do passado presente: modernismos, artes visuais, políticas da memória. Rio de Janeiro, Contraponto: Museu de Arte do Rio, 2014. 216p.

JELIN, Elizabeth. Los trabajos de la memoria. Madrid: Siglo Veintiuno de España, 2002. 146p.

La lucha por el pasado: Cómo construimos la memoria social. Buenos Aires: Siglo XXI Editores, 2017. 302p.

LONGONI, Ana e BRUZZONE, Gustavo (org.). El Siluetazo. Buenos Aires: Adriana Hidalgo, 2008. $514 \mathrm{p}$. 
MEMORIA ABIERTA. Memórias en La ciudad: Señales Del terrorismo de Estado en Buenos Aires. Buenos Aires: Memória Abierta/EUDEBA, 2009. 240p.

SILVESTRI, Graciela. El arte en los límites de representación. Revista Punto de Vista. Buenos Aires, n. 68, p. 18-24, 1999.

TAYLOR, Diana. O Trauma como performance de longa duração. O Percevejo. Rio de Janeiro, v. 1, n. 1, p. 2-9, 2009.

VEZZETTI, Hugo. História e memorias del terrorismo de estado en la Argentina. Working Paper n. 8. Maryland: Latin American Studies Center, University of Maryland, 2001. 26p. Disponível em: <http://www.lasc.umd.edu/documents/working_papers/new_lasc_series/08_vezzetti.pdf> . Acesso em 15/05/2018.

Pasado y presente: Guerra, ditadura y sociedad en la Argentina. Buenos Aires, Siglo Veintiuno Editores, 2002.

Sobre la violência revolucionaria: memorias y olvidos. Buenos Aires, Siglo Veintiuno Editores, 2009.

La memoria justa: política e historia en la argentina del presente. En: BOHOSLAVSKY, Ernesto et al. Problemas de historia reciente del Cono Sur. v. 2. Buenos Aires: Prometeo Libros, p. 81-97, 2010.

Recebido em: 31 de dezembro de 2017

Aprovado em: 03 de junho de 2018 